\title{
Augusta Marie Déjerine-Klumpke: much more than just Déjerine's wife
}

\author{
Augusta Marie Déjerine-Klumpke: muito mais do que apenas a esposa de Déjerine \\ Eduardo de Almeida Guimarães Nogueira', Vitor Martinez de Carvalho', Marcos Vinicius de Queiroz', \\ Gleysson Rodrigues Rosa ${ }^{2}$, Yara Dadalti Fragoso'
}

\begin{abstract}
Augusta Marie Déjerine-Klumpke (1859-1927) was a formidable neurologist, neuroanatomist and researcher in France. One of the first women to be accepted for medical internship, externship and research in Paris, Augusta made her name studying and teaching anatomy, histology and dissection, attending clinical activities in neurology, obstetrics, pediatrics and neurologic trauma, performing necropsies, and writing scientific papers and book chapters. Her main research in neurology awarded her an eponym for the avulsion of the lowest root of the brachial plexus (Klumpke's palsy). Married to her professor, the remarkable Dr. Joseph Jules Déjerine, Augusta continued her career and became the first female president of the French Society of Neurology.
\end{abstract}

Key words: brachial plexus neuropathies; neurology; history.

\section{RESUMO}

Augusta Marie Déjerine-Klumpke (1859-1927) foi uma formidável neurologista, neuroanatomista e pesquisadora na França. Uma das primeiras mulheres aceitas para estágios médicos internos e externos ao hospital, e pesquisa em Paris, Augusta fez seu nome estudando e ensinando anatomia, histologia e dissecção, participando de atividades clínicas em neurologia, obstetrícia, pediatria e trauma neurológico, participando de necrópsias, e escrevendo artigos científicos e capítulos de livros. Sua principal pesquisa em neurologia lhe rendeu um epônimo para a avulsão da raiz inferior do plexo braquial (paralisia de Klumpke). Casada com seu professor, o notável Dr. Joseph Jules Déjerine, Augusta continuou sua carreira e se tornou a primeira mulher presidente da Sociedade Francesa de Neurologia.

Palavras-chave: neuropatias do plexo braquial; neurologia; história.

A female physician in the late 1800s must have had a difficult time establishing her place in professional circles. A female neurologist and neuroanatomist who was married to a famous professor at Salpêtrière (who happened to be her teacher) must have had an even harder task.

Augusta Déjerine-Klumpke (1859-1927) was born in San Francisco, California, USA. She was the second of the six children of John Klumpke, an English business man, and Dorothea, his American wife ${ }^{1,2}$. Following medical advice after her eldest child was diagnosed with severe osteomyelitis, Dorothea moved to Germany with her children for a couple of years ${ }^{3}$. They then returned to the USA, but Dorothea and John subsequently divorced and Dorothea moved back to Germany with the children ${ }^{4}$. During a vacation, Dorothea talked to a Parisian woman, who mentioned that Paris could provide for all the careers that the children might happen to choose $\mathrm{e}^{3}$. Almost on a whim, Augusta's mother moved to Paris with her children².

Augusta could already speak several languages, including French. Inspired by Madeleine Brès, a pioneering woman in the medical profession in France ${ }^{4}$, Augusta decided to be a doctor $^{1}$. At that time, women were required to enter medical classes through a separate door, and to sit in a particular section of the classroom, where they were often subjected to verbal abuse from their male classmates ${ }^{5}$.

During her second year as a medical student, Augusta took Professor J.A. Fort's intensive course on anatomy and dissection, and qualified to work as his assistant for the next two years $^{1}$. That gave her enough experience to win the Vermeil Medal for free teaching in a contest for an internship in one of the hospitals in Paris. She also worked in Dr. Latteux's histology laboratory at the same time, and on Sunday mornings

'Universidade Metropolitana de Santos, Departamento de Neurologia, Santos SP, Brasil;

${ }^{2}$ Harvard Medical School, Spaulding Rehabilitation Hospital, Department of Physical Medicine and Rehabilitation, Charlestown, MA USA.

Correspondence: Yara Dadalti Fragoso; Departamento de Neurologia, Faculdade de Medicina / UNIMES; Avenida Conselheiro Nebias, 536; $11045-002$ Santos SP, Brasil; E-mail:yara@bsnet.com.br

Conflict of interest: There is no conflict of interest to declare.

Received 14 September 2017; Received in final form 30 October 2017; Accepted 31 October 2017. 
she attended lectures given by Charcot at the Salpêtrière Hospital and by Magnan at the Sainte-Anne Asylum ${ }^{1}$.

In 1880, Miss Klumpke was accepted for an internship in Professor Alfred Hardy's unit in the Hôpital de la Charité. Dr. Joseph Jules Déjerine, who would become her husband eight years later, also worked at this hospital. In Augusta Klumpke's own words, the years spent at the Hôpital de la Charité were very interesting: "These years were much more interesting than the mere study of books for preparing an examination ${ }^{3}$ ". For two years, she followed clinical activities and classes, took patients' histories, performed autopsies and was introduced to scientific research ${ }^{3}$.

In 1882, she became involved in obstetrics and pediatric diseases. During the same year, thanks to Blanche Edwards (another pioneer of French women's rights) ${ }^{4}$, Augusta entered a contest for externships at hospitals in Paris. Blanche and Augusta together became the first women to be accepted for externships in the history of French medicine.

In 1883, Augusta Klumpke began her externship at the Hôtel-Dieu and dedicated her research to radicular palsy of the upper brachial plexus (Erb's palsy). Augusta described a patient with avulsion of the lowest root of the brachial plexus (T1 level), presenting with ipsilateral Horner's syndrome (the result of concomitant injury to the adjacent sympathetic chain), with paralysis of the small hand muscles (claw hand) and sensory loss along the ulnar side of the forearm. To this day, this syndrome is called "Klumpke's palsy"7. Klumpke's palsy may result from a difficult breech delivery or from upper plexus injuries following a violent dislocation between the shoulder and the neck, as seen in motorcycle or car accidents ${ }^{6}$. Augusta Klumpke had her study published in Revue de Médecine and won the prestigious Godard prize from the Academy of Medicine ${ }^{3,6}$.

On July 14, 1888, Augusta married her professor, Déjerine, who was her senior by 10 years. He often said that "she had all the possible positive attributes" («Elle a toutes les qualités possibles») ${ }^{8}$. Together they made a formidable pair within neurology. Augusta's contributions to Jules Déjerine's textbooks were remarkable, as she was also a skilled illustrator, and she participated in a two-volume textbook of neuroanatomy with her husband. Augusta Déjerine-Klumpke became the first woman to become president of the French

\section{A}

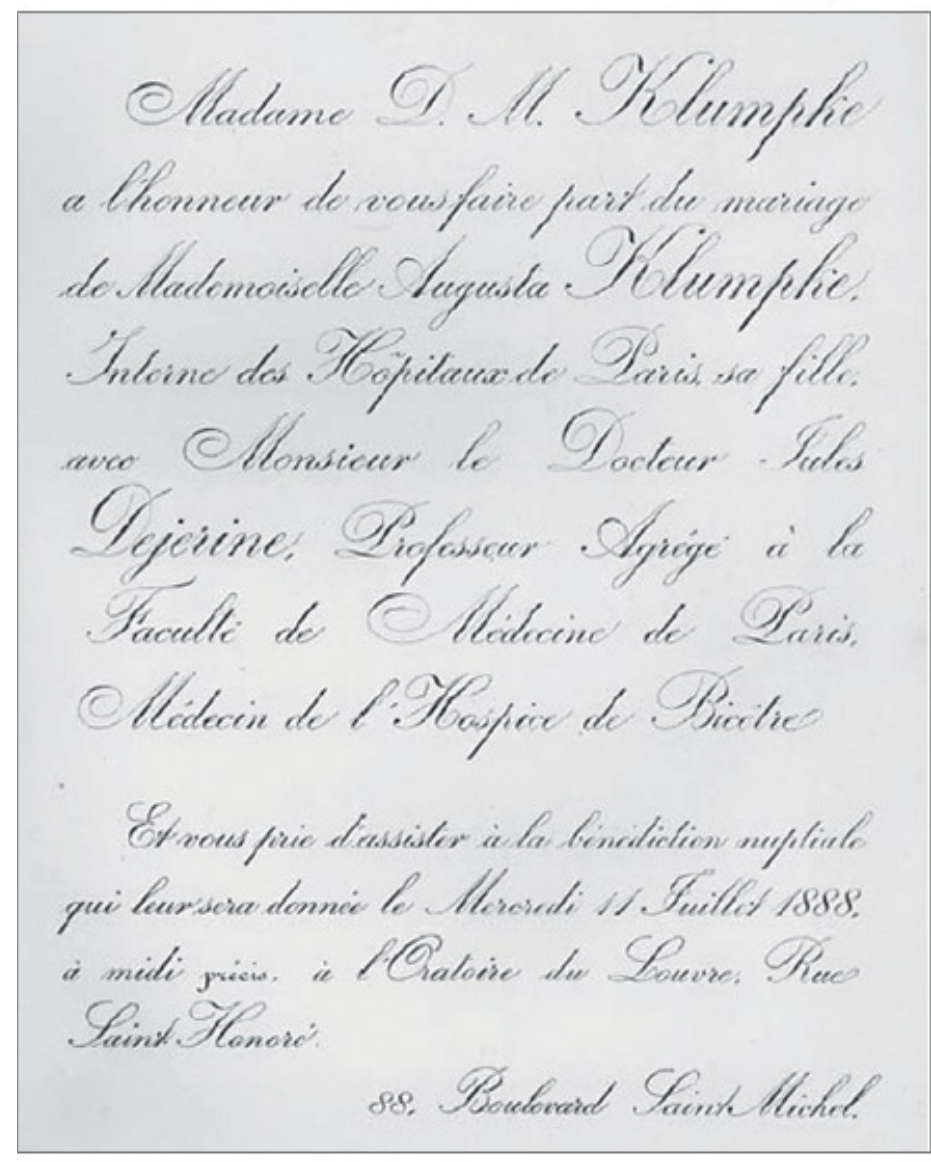

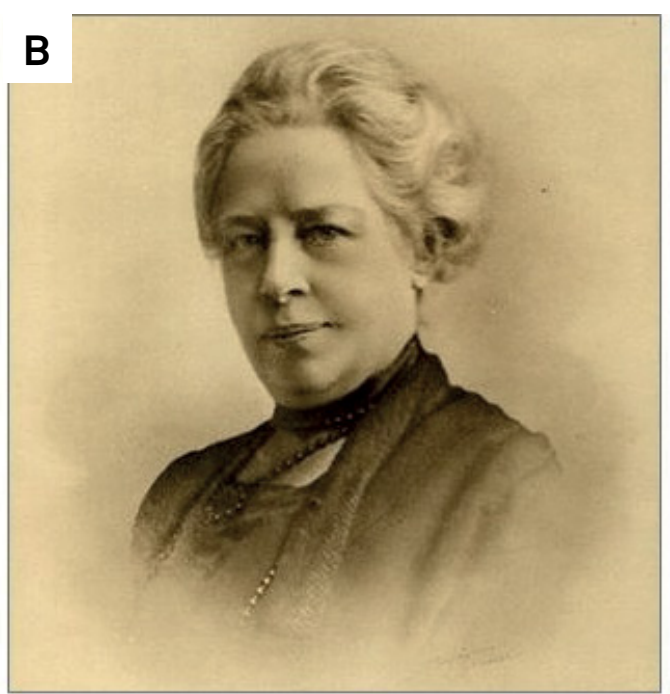

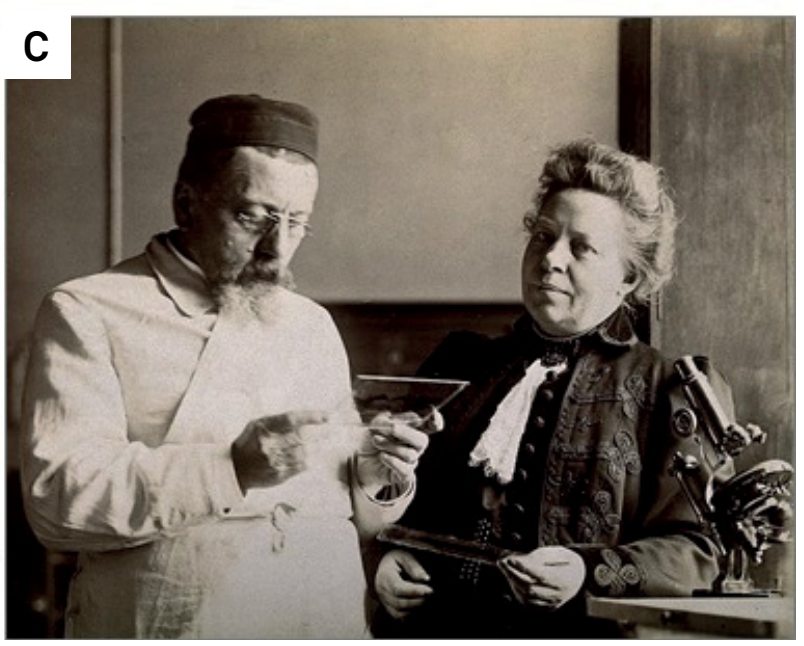


Society of Neurology, in $1914^{3}$. Figure 1 shows their marriage communication, and photos of the young Augusta and of the Déjerine couple. Figure 2 shows the title page of Anatomie des Centres Nerveux, published in 1895 by Jules Déjerine and Madame Déjerine-Klumpke, two schematic drawings made by Augusta Déjerine-Klumpke, and the title page of her thesis.
Ninety years ago, in 1927, Augusta died at the age of 68, after having published 56 articles. She worked fiercely in the treatment and rehabilitation of First World War soldiers who had been neurologically wounded ${ }^{3,6,9}$. For her work during the war, she was awarded the title of Chevalier de la Légion d'honneur. To this day, there is no "Chevalière" title, and women can only be appointed as "Chevaliers".
A

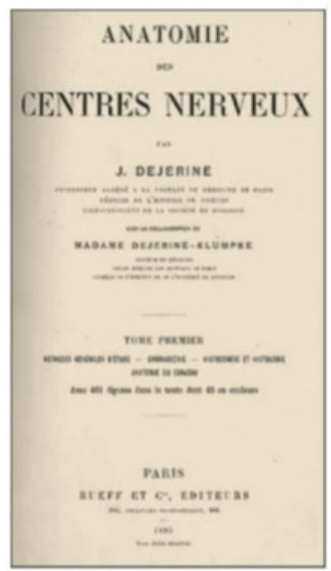

B

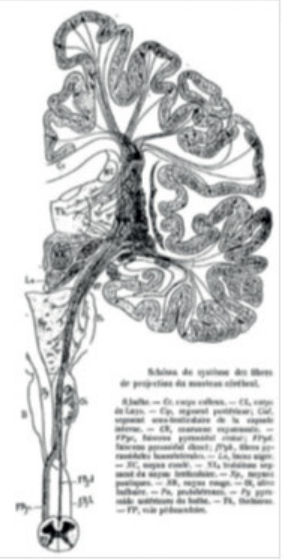

C

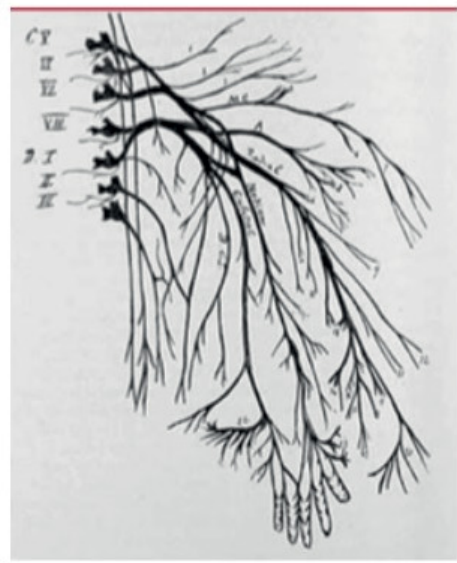

D

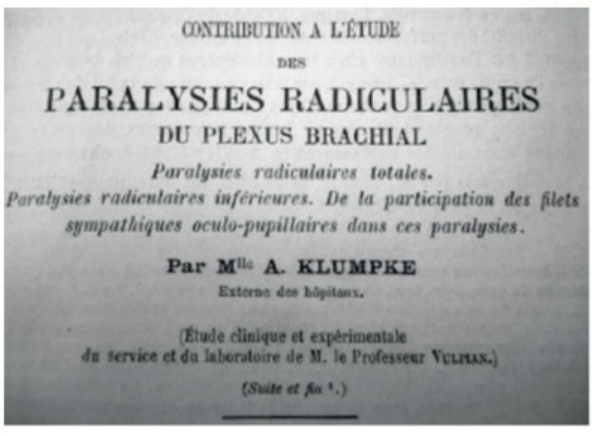

Figure 2. (A)The title page of Anatomie des Centres Nerveux published in 1895 by Jules Déjerine and Madame Déjerine-Klumpke; (B) schematic drawings of the projecting fibers to the brain and (C) the anatomy of the brachial plexus, both illustrated by Augusta Déjerine-Klumpke; (D) the title page of Madame Déjerine-Klumpke thesis that covered 295 pages on the anatomy and lesions of

the brachial plexus.

\section{References}

1. Berhoune NN, Thobois S, Gobert F, Campean L, Broussolle E. Augusta Dejerine-Klumpke (1859-1927): an extraordinary neurologist and an inspiration for all women in medical careers. Pediatr Neurol. 2014 Jun;50(6):547-8. https://doi.org/10.1016/j.pediatrneurol.2014.01.044

2. Fernández-Vázquez JM, Camacho-Galindo J, Ayala-Gamboa U. [Augusta Marie Dejerine-Klumpke]. Acta Ortop Mex. 2012 May-Jun;26(3):207-8. Spanish.

3. BogousslavskyJ. The Klumpke family: memories by Doctor Déjerine, born Augusta Klumpke. Eur Neurol. 2005;53(3):113-20. https://doi.org/10.1159/000085554

4. Hakulinen E. [Madeleine, Augusta and Blanche. The first fighters of the barricades for women physicians in France]. Lakartidningen. 2001 Dec;98(50):5786-9. Swedish.
5. Lecours AR, Caplan D. Augusta Dejerine-Klumpke or "The Lesson in Anatomy”. Brain Cogn. 1984 Apr;3(2):166-97. https://doi.org/10.1016/0278-2626(84)90015-0

6. Yildirim FB, Sarikcioglu L. Augusta Dejerine-Klumpke (1859-1927) and her eponym. J Neurol Neurosurg Psychiatry. 2008 Jan;79(1):102. https://doi.org/10.1136/jnnp.2007.123448

7. Ellis H. Augusta Klumpke: pioneering female neurologist. Br J Hosp Med (Lond). 2009Jan;70(1):41. https://doi.org/10.12968/hmed.2009.70.1.37694

8. Augusta Marie Klumpke épouse Déjerine: 1859-1927: première femme interne des Hôptaux de Paris. Medarus.org. 2017 [acess 2017 Oct 30]. Disponível em: http://medarus.org/Medecins/ MedecinsTextes/klumpke_augusta.html

9. Gomes MM. French school and World War first: neurological consequences of a frightening time. Arq Neuropsiquiatr. 2015 May;73(5):463-5. https://doi.org/10.1590/0004-282X20150031 